\title{
Reflections on Scienter (and the Securities Fraud Case Against Martha Stewart that Never Happened)
}

Donald C. Langevoort

Georgetown University Law Center, langevdc@law.georgetown.edu

This paper can be downloaded free of charge from:

https://scholarship.law.georgetown.edu/facpub/141

10 Lewis \& Clark L. Rev. 1-17 (2006)

This open-access article is brought to you by the Georgetown Law Library. Posted with permission of the author. Follow this and additional works at: https://scholarship.law.georgetown.edu/facpub

Part of the Securities Law Commons 


\title{
GEORGETOWN LAW Faculty Publications
}

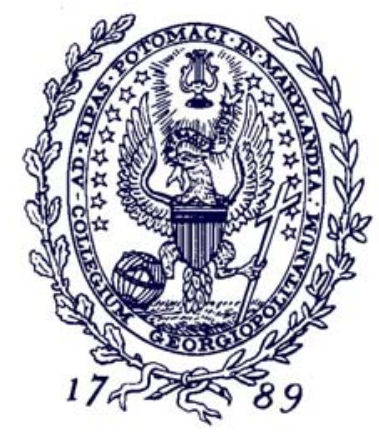

January 2010

\section{Reflections on Scienter (and the Securities Fraud Case Against Martha Stewart that Never Happened)}

10 Lewis \& Clark L. Rev. 1-17 (2006)

\author{
Donald C. Langevoort \\ Professor of Law \\ Georgetown University Law Center \\ langevdc@law.georgetown.edu
}

This paper can be downloaded without charge from:

Scholarly Commons: http://scholarship.law.georgetown.edu/facpub/141/

Posted with permission of the author 


\title{
REFLECTIONS ON SCIENTER (AND THE SECURITIES FRAUD CASE AGAINST MARTHA STEWART THAT NEVER HAPPENED)
}

\author{
by \\ Donald C. Langevoort
}

\begin{abstract}
This paper considers what research in cognitive psychology and behavioral economics has to say about one of the basic "state of mind" constructs in the law of fraud: scienter. It takes a clinical approach, examining the securities fraud case that never happened against Martha Stewart. In granting a judgment of acquittal in Stewart's favor on the securities fraud charge, the court seemingly misunderstood the law of scienter, which turns on awareness rather than purpose. But that simply provides an opportunity to think about what awareness means in the context of financial transactions. From publicly available sources, interesting inferences can be drawn about what Martha Stewart was thinking (and feeling) during the events at issue.
\end{abstract}

I. MARTHA STEWART'S ALLEGED CRIMINAL SECURITIES

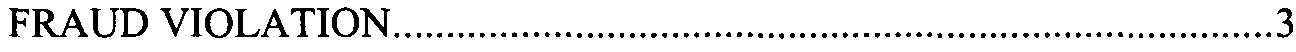

A. The Story .......................................................................................

B. The Dismissal of the Securities Fraud Claim .........................................

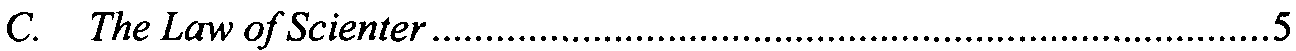

D. A Cognitive Perspective on Defining Scienter......................................

II. MARTHA STEWART'S INSIDER TRADING ......................................11

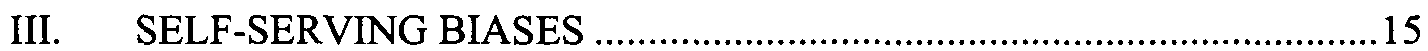

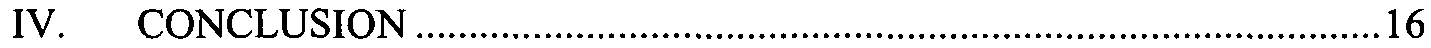

Behavioral law and economics normally works at a high level of generality, predicting how people commonly make judgments and decisions in certain broad classes of situations, and deriving policy prescriptions from those predictions. This can be a useful exercise when done properly, though it inevitably draws the criticism that real-life situations vary enough (not to mention actors themselves) that such generalizations are dangerous in applied settings. ${ }^{1}$

A less common approach is to be clinical: focusing attention on an observed judgment or decision and using the tools of psychology to try to

* Thomas Aquinas Reynolds Professor of Law, Georgetown University Law Center. Thanks to Meir Statman for comments on an earlier draft, and to faculty and students at Georgetown, Stetson, Temple, and the Lewis \& Clark forum for helpful feedback.

' E.g., Gregory Mitchell, Why Law and Economics' Perfect Rationality Should Not be Traded for Behavioral Law and Economics' Equal Incompetence, 91 GEO. L.J. 67 (2004). 
explain what otherwise might seem to be puzzling behavior. Though risky because single observations will not always conform to even the most wellestablished behavioral predictions, this exercise has the virtue of presenting a richly defined situation as a reality check. From a legal perspective, this exercise can be used to evaluate that behavior-by understanding it better, we might become better able to assess its blameworthiness, for example.

This paper will do some of both. My interest is in scienter under the law of fraud, particularly as applied under Rule $10 \mathrm{~b}-5$ of the Securities Exchange Act of 1934. Although it is clear that $10 \mathrm{~b}-5$ has a scienter requirement, ${ }^{2}$ its exact contours--indeed, what at heart the requirement really means - may still not be entirely certain. ${ }^{3}$ One aim of this paper is to consider various formulations of scienter offered by the courts and test how well they are likely to fit the cognitions of actors in the financial marketplace in light of what we know or suspect from recent psychological research.

To be concrete about this, I will examine the 10b-5 case against Martha Stewart. As most readers know, Stewart-the home products celebrity and then-CEO of her own publicly traded company, Martha Stewart Living Omnimedia (MSLO) - was tried and convicted in 2004 on federal charges involving the making of false statements to the government, arising out of an SEC and FBI investigation into her alleged insider trading in the shares of ImClone, a biotechnology company. ${ }^{4}$ Prosecutors chose not to charge her for the insider trading itself (though the SEC did bring a parallel civil insider trading case against her, which is still pending). ${ }^{5}$ The prosecutors did charge her with a $10 \mathrm{~b}-5$ violation for lying publicly about the investigation in a way that allegedly influenced the price of MSLO stock. Late in the trial, however, the court granted a judgment of acquittal on the securities fraud charge, ${ }^{6}$ so that the case went to the jury only on the obstruction and false statement claims.

I think that the court was wrong on this as a matter of law, which I will explain. But my main point is that the underlying interpretive issue exposes how porous the definition of scienter is from a psychology perspective when applied in a difficult case. This is not to say that Stewart was innocent of a 10b5 violation-I think there is evidence to suggest that she did act with scienter as

2 Ernst \& Ernst v. Hochfelder, 425 U.S. 185, 214 (1976). Hochfelder was clear in its rejection of negligence as an appropriate state of mind standard: otherwise, it spoke only in dicta of scienter as "a mental state embracing intent to deceive, manipulate or defraud" and as action other than in good faith. Id. at 193 n.12. See generally James D. Cox, Ernst \& Ernst v. Hochfelder: A Critique and an Evaluation of Its Impact upon the Scheme of the Federal Securities Laws, 28 HASTINGS L.J. 569 (1977).

3 See James D. Cox ET Al., Securities Regulation: CASES and Materials 648-51 (4th ed. 2004).

4 She was charged with other related crimes, including obstruction of justice and conspiracy.

5 SEC v. Stewart, SEC Litig. Release No. 18169, 2003 WL 21278259 (S.D.N.Y. June 4 , 2003) [hereinafter SEC Litig. Release]. The SEC's formal complaint, which contains a more detailed statement of the case against Stewart, is attached to the release.

6 United States v. Stewart, 305 F. Supp. 2d 368 (S.D.N.Y. 2004); see Jury Convicts Martha Stewart on Conspiracy, Obstruction Charges, 36 SEC. REG. \& L. REP. (BNA) 425 (March 8, 2004). 
commonly understood. I simply want to use the issues surrounding her case to emphasize the troubling distance between how the legal system applies state of mind rules and how social scientists think about concepts such as awareness and motivation.

Of course a legal realist would point out that scienter as applied is not what was actually going on in the mind of the defendant at the time, but rather what the judge or jury thinks was going on. The cognitive biases we should be considering, then, are not those of the actor but of the evaluator asked to determine the defendant's state of mind. I agree, and concede the likelihood that such familiar cognitive regularities as the hindsight bias and the fundamental attribution bias will often lead to fact-finding that does not accurately describe the defendant's true state of mind. ${ }^{7}$ My main point- that many actors in the corporate setting or the financial markets mislead others without scienter as that requirement is defined as a matter of law-may well in reality be offset by the fact that judges or juries may find them guilty or liable anyway.

But that makes the normative question all the more troubling. Precisely what kind of mental state is deserving of the penalties associated with securities fraud? How strict should the scienter requirement be? Especially after the recent financial scandals and the Sarbanes-Oxley Act of 2002, a finding of securities fraud can bring rather draconian penalties, in terms of fines, civil judgments, and serious jail time. Understanding the psychological aspects of securities fraud is important at least to help us fit the remedy to the wrong.

\section{MARTHA STEWART'S ALLEGED CRIMINAL SECURITIES FRAUD VIOLATION}

\section{A. The Story}

As charged by government authorities, Martha Stewart's legal troubles began on December 27, 2001. ${ }^{8}$ The day before, insiders at ImClone learned that

7 See Jeffrey J. Rachlinski, A Positive Psychological Theory of Judging in Hindsight, 65 U. CHI. L. Rev. 571 (1998); Donald C. Langevoort, Where Were the Lawyers? A Behavioral Inquiry into Lawyers' Responsibility for Clients' Fraud, 46 VAND. L. REv. 75, 108-09 (1993); Donald C. Langevoort, Organized Illusions: A Behavioral Theory of Why Corporations Mislead Stock Market Investors (and Cause Other Social Harms), 146 U. PA. L. REV. 101, 158 n.199 (1997) [hereinafter Langevoort, Organized Illusions]. The psychology of jury decision-making is obviously a major research area. See e.g., Reid Hastie et al., Juror Judgments in Civil Cases: Hindsight Effects on Judgments of Liability for Punitive Damages, 23 LAW \& HUM. BeHaV. 445 (1999).

8 This account is taken from the criminal indictment, which I am assuming (in light of the conviction by the jury) to be true, and the SEC's civil complaint. See Superseding Indictment, U.S. v. Stewart, 323 F. Supp. 2d 606 (S.D.N.Y. 2004) (03 Cr. 717 (MGC)) [hereinafter Stewart Superseding Indictment]; SEC Litig. Release, supra note 5. Obviously, the true facts may be different. For other commentaries on the securities fraud claim, see Joan MacLeod Heminway, Martha Stewart Saved! Insider Violations of Rule 10b-5 for Misrepresented or Undisclosed Personal Facts (unpublished manuscript); Dale A. Osterle, 
the FDA would take adverse action with respect to its key anti-cancer drug under development, Erbitux. (The securities markets were anxiously awaiting a decision from the FDA; it was public knowledge that the FDA had until the last day of December to decide one way or the other.) For reasons that themselves are hard to fathom given the unambiguous legal risk associated with such behavior, this news led ImClone's CEO, Sam Waksal, to try to sell his stock, and he succeeded in causing his daughter and father to sell out their holdings. Waksal's efforts to sell were channeled through his stockbroker at Merrill Lynch, Peter Bacanovic, who was also Stewart's broker. ${ }^{9}$ Through his assistant, Bacanovic communicated to Stewart on the 27th that the price of ImClone was likely to be trading downward and that the Waksals were selling, which caused Stewart to direct that all of her ImClone stock be sold immediately. The price thereafter continued to fall, so that by selling when she did rather than at the bottom of the market, Stewart avoided a loss of approximately $\$ 45,000$, an extraordinarily small amount compared to her total net worth. ${ }^{10}$

A federal investigation was commenced almost immediately, with Stewart readily identified as a seller with ties to Bacanovic, Waksal, and ImClone. ${ }^{11}$ Stewart voluntarily appeared in early February and told investigators that she and Bacanovic had recently reviewed her portfolio and come to an understanding, among other things, that her ImClone stock should be sold should the price fall to $\$ 60$ per share from the $\$ 70$ or so that it was trading at in the late fall. Because the price fell below $\$ 60$ on December 27, the sell order was triggered. She denied receiving any information about ImClone or the Waksals in the call that afternoon.

The government's ImClone investigation continued throughout the spring, and led to a Congressional inquiry as well. Eventually, the press learned of Stewart's situation and she was asked to comment. Through her attorney, she told reporters the same story that she had told investigators, i.e., that she was not guilty of any insider trading because she had received no inside information and that the sales were the result of the pre-arranged plan to sell at $\$ 60$, and these responses appeared in print on June 7. Essentially, this was repeated in a more elaborate press release on June 12 and a meeting with securities analysts covering MSLO on June 19.

Largely based on cooperative testimony from the broker's assistant in return for leniency, the investigators came to believe that Stewart's testimony and public statements were false- that there was no pre-existing sell order, and that such a story had been fabricated (and an effort made to falsify documents)

Early Observations on the Prosecutions of the Business Scandals of 2002-03: On Sideshow Prosecutions, Spitzer's Clash with Donaldson Over Turf, the Choice of Civil or Criminal Actions, and the Tough Tactic of Coerced Cooperation, 1 OHIO ST. J. CRIM. L. 443 (2004).

9 Importantly, Stewart and Waksal were also close friends; Waksal had once dated Stewart's daughter, and he and Stewart socialized frequently. For an interesting background on the Stewart case, including the trial, see Jeffrey Toobin, A Bad Thing: Why Did Martha Stewart Lose?, THE NEW YORKER, Mar. 22, 2004, at 61.

10 The irony is that the FDA eventually gave its approval to Erbitux, and by the time Stewart was being sentenced to prison, ImClone shares were trading at around $\$ 85$ per share.

11 Merrill Lynch compliance officials set the investigation in motion. 
as part of a cover-up devised by Stewart and Bacanovic once they learned of the investigation. In the prosecutors' view this supported both the obstruction and securities fraud charges, because the lies were directed to both the government and the investing public (purchasers and sellers of MSLO shares). As noted, the criminal indictment was silent with respect to the alleged insider trading.

\section{B. The Dismissal of the Securities Fraud Claim}

Stewart moved for of a judgment of acquittal pursuant to Rule 29 of the Federal Rules of Criminal Procedure, which the court granted with respect to the one securities fraud count late in the trial. ${ }^{12}$ As the court framed the issue, the question was whether a jury could find beyond a reasonable doubtwithout mere speculation - that Stewart acted with scienter in making false statements to the investing public. The court did not address the question of whether the "willfulness" standard application to criminal prosecutions under Rule $10 \mathrm{~b}-5$ required a different state of mind showing than in a civil case. The prosecution offered evidence that Stewart was the controlling shareholder of MSLO and regularly concerned with the company's stock price (as a result of publicity about the government's investigation, the price of MSLO stock dropped by more than 30 percent). The inference was that Stewart had lied to counteract the downward pressure on the stock.

The court ruled that a reasonable jury could not find beyond a reasonable doubt that Stewart intended to deceive investors, even assuming the falsity of her public statements. As the court saw it, the question was whether her "purpose was to influence the market in MSLO securities." ${ }^{\text {.13 }}$ Essentially, the court thought that there were too many other possible purposes for a jury to reach that level of certainty:

Here, the evidence and inferences... are simply too weak to support a finding beyond a reasonable doubt of criminal intent. To compound that weak evidence with the reasonable inferences that Stewart possessed many other intents - to protest her innocence or repair her reputation, to reassure her business partners, advertisers, and the consumers of her products-would only invite the jury to speculate. ${ }^{14}$

\section{The Law of Scienter}

The court seems to have misunderstood the law. There has been a longstanding issue about whether purpose or motivation should be relevant to the scienter determination, and one can find occasional dicta that suggests that that

12 Thereby making it non-appealable. The court had earlier refused to dismiss the securities charge, which had been argued by Stewart's lawyers largely on grounds that the June statements were immaterial as a matter of law.

13 United States v. Stewart, 305 F. Supp. 2d 368, 376 (S.D.N.Y. 2004) (emphasis added).

14 Id. at 378. 
purpose is relevant. ${ }^{15}$ But the weight of authority is that the relevant question is not motive or purpose but awareness-did the defendant know or recklessly disregard that what she was saying was false $?^{16}$ The clearest statement of this, ironically, came in the only securities case cited by the court in its opinion (albeit on a different point of law), AUSA Life Insurance Co. v. Ernst \& Young. ${ }^{17}$ There, the Second Circuit admonished the trial court because it "inappropriately [made] the scienter issue one of "what did the defendant want to happen' as opposed to 'what could the defendant reasonably foresee as a potential result of his action." 18 That, of course, is exactly what the court did in Stewart, too. If one uses forseeability as the test, there were ample grounds for inferring that Stewart understood the likely impact of her lie on the MSLO market. Indeed, that was precisely how the prosecution had presented its evidence.

In fact, forseeability may not be the precise articulation either if what we are talking about is scienter. An appreciation of the falsity by the speaker is all that is necessary. The forseeability standard goes to something slightly different, subject-matter jurisdiction as embodied in the requirement that the fraud be "in connection with the purchase or sale of a security." Not all fraud is securities fraud, and the prevailing "in connection with" standard is whether the defendant's misrepresentation or omission was "reasonably calculated to influence the investing public." 19 Though the word "calculated" might connote purpose or motivation, courts have instead said - consistent with the scienter standard-that the test is whether the defendant appreciated the likely effect on investors, with forseeability being the best way to answer that question. ${ }^{20}$ In this way, $A U S A$ was conjoining the scienter and "in connection with" tests in a way that makes holistic sense in defining what constitutes securities fraud.

The awareness or appreciation standard-as opposed to motive or purpose- finds support in the way that the case law has evolved on a number of points. In dicta, the Supreme Court essentially endorsed it in Basic Inc. $v$. Levinson when it rejected the idea that showing a "good business purpose" for

15 See State Teachers Ret. Bd. v. Fluor Corp., 654 F.2d 843, 850 (2d Cir. 1981). Fluor is an ambiguous precedent because the court was facing the problem of a company's affirmative duty to disclose, which it saw as presenting a separate problem.

16 See SEC v. Falstaff Brewing Co., 629 F.2d 62, 76 (D.C. Cir. 1980); 5C ARNold S. JACOBS, DisClosURE AND REMEDIES UNDER THE SECURITIES LAWS $\S 12: 75$ (2001); 3B HAROLD S. BlOOMENTHAL \& SAMUEL WOLFF, SECURITIES AND FEDERAL CORPORATE LAW § 13.20 (2d ed. 2005) ("intent to deceive was actionable at common law irrespective of motive or purpose": rule is the same under Rule 10b-5). One important consequence-quite relevant to the question in Stewart - is that one can be liable under 10b-5 even if the deception of investors was simply a consequence of a plan to deceive someone else (e.g., a defense contractor lying to the Defense Department). See Heit v. Weitzen, 402 F.2d 909 (2d Cir. 1968).

206 F.3d 202 (2d Cir. 2000).

${ }^{18}$ Id. at 221.

19 SEC v. Texas Gulf Sulphur Co., 401 F.2d 833, 862 (2d Cir. 1968) (en banc).

20 See Semerenko v. Cendant Corp., 223 F.3d 165 (3d Cir. 2000); In re Carter Wallace Sec. Litig., 150 F.3d 153 (2d Cir. 1998); In re Ames Dep't Store Stock Litig., 991 F.2d 953 (2d Cir. 1993). 
a misrepresentation would insulate a defendant from liability. ${ }^{21}$ It is also implicit in the now nearly universal recognition that recklessness suffices as the basis for scienter ${ }^{22}$-reckless disregard of the truth goes to the defendants' awareness or appreciation, not purpose.

Understanding why the court took such a wrong turn in rejecting the prosecution's securities fraud case against Stewart is hard; there is no legal analysis or citation of cases on this point. One possibility, which should be guarded against, is that the court was confused by the substantial body of law on pleading scienter under the heightened pleading standard of the Private Securities Litigation Reform Act. ${ }^{23}$ There is a vast amount of case law about whether showing a strong enough motive will satisfy that burden, and the Second Circuit is one of the more receptive to motive-based analysis. ${ }^{24}$ Because pleading cases are by far the most frequent context in which the issue is raised, it might be easy for a trial judge to think that the scienter requirement itself is about motive. However, the questions are entirely different. The pleading requirement is about whether plaintiffs get to go to discovery, where solid evidence about awareness or appreciation can be elicited through document production and depositions. Allegations of motive are made important because they help distinguish between strong and weak cases at that early stage, before the pressure to settle becomes overwhelming. But at the trial stage-after discovery has been allowed-the standard becomes the conventional one (although motive and opportunity may still be relevant evidence in arguing a circumstantial case of knowledge or recklessness).

Is it possible that the error was harmless? That would be so if there were some separate ground for making Stewart's purpose the controlling question. In a criminal case, violations of Rule 10b-5 must not only be with scienter but also "willful"- a stricter state of mind that arguably supports a motivation (specific intent) test. But here again, there is no compelling support in the case law. The Second Circuit has indicated that willfulness requires a realization on the part of the defendant that he was acting "wrongfully," which may (or may not) be something more than simply awareness of the falsity. ${ }^{25}$ If we assume that Stewart knew that what she was saying was untrue, it is hard to find a lack of willfulness simply because her lie might have been directed more to the consuming public or company stakeholders than to investors. ${ }^{26}$

21485 U.S. 224, 239 n.17 (1988).

22 See, e.g., Greebel v. FTP Software, Inc., 194 F.3d 185 (1st Cir. 1999); JAMES D. CoX ET AL., SECURities Regulation: CASES AND MATERIALS 650 (4th ed. 2004).

${ }^{23}$ This seems to have been the case in AUSA, Life Ins. Co. See 206 F.3d at 221 n.12.

24 See, e.g., Novak v. Kosaks, 216 F.3d 300 (2d Cir. 2000).

${ }^{25}$ See United States v. Dixon, 536 F.2d 1388 (2d Cir. 1976). Arguably, however, this is too strict: some believe that willfulness only requires that the defendant simply know the facts that underlie the offense. See William H. Widen, Enron at the Margin, 58 Bus. LAW. 961 (2003); Norwood P. Beveridge, Is Mens Rea Required for a Criminal Violation of the Federal Securities Laws?, 52 Bus. LAw. 35 (1996).

${ }^{26}$ Had Stewart simply (but assume falsely) proclaimed her innocence without giving any specific factual details, there is a good chance that this would be treated as the equivalent of puffery (i.e., immaterial as a matter of law)-a general statement of the sort 
The judgment of acquittal seems to have been a legal error, then, substantially in Stewart's favor. If so, it was also a material error, because had the jury convicted her of securities fraud as well as making false statements, the likely criminal sentence would have been far greater than the five months she served. Especially after Sarbanes-Oxley, the likely sentence would have been crippling. ${ }^{27}$

\section{A Cognitive Perspective on Defining Scienter}

One contribution that the cognition research can offer is to help understand the nature and consequences of one approach or another to a legal standard like scienter. To me, the research strengthens the preference for an "awareness" standard rather than one based on motivation or purpose. Motivation is extraordinarily complex, and often unconscious. The conscious perception of one's own motive is often inaccurate- a rationalization designed to buffer anxiety or guilt, or maintain self-esteem. If securities fraud wants to reach harmful behavior, it should not let cognitive excuses (for example, a lie by Martha Stewart that she thought was necessary to protect company employees or customers who were so heavily invested in her brand) be relevant.

That said, we should realize that the preferable "awareness" standard is also on somewhat shaky cognitive ground. Although much of the judgment and decision-making literature deals with choice (especially risky choice) rather than perception, the two are inseparable - choices are largely defined by how the prevailing situation is perceived. And the psychology literature is filled with studies of how peoples' mental models of reality can diverge from reality objectively defined. There is a wonderfully metaphorical illustration of this created by University of Illinois researcher Daniel Simons, familiar to many who have been introduced to the behavioral research. ${ }^{28}$ An audience is asked to watch a short video of a group of people moving about passing a basketball, some in black shirts, others in white. The audience is asked to pay close attention and count the number of times those dressed in one color catch the ball. This is not easy because of the rapid movements of the crowd in a confined space. When the viewing is over, the presenter asks the audience for the right number. Most come fairly close; many get it correct.

Then the presenter asks how many people noticed the man in the gorilla

expected from a defendant regardless of guilt, and thus not taken seriously by the reasonable investor. Indeed, in its motion to dismiss, the Stewart defense argued that even the broader set of denials and explanations by Stewart should be deemed immaterial. Arguably, she could argue that she foresaw no market impact because she assumed that sophisticated investors would treat her denials as puffery (which would merge the materiality into a scienter analysis), but it is difficult to see how this could be accepted as a matter of law, without factual inquiry into her thinking.

27 Waksal was sentenced to seven years in prison, though the counts against him included tax evasion as well. See Leslie Eaton, The Ghost of Waksal Past Hovers Over the Stewart Trial, N.Y. TIMES, Feb. 17, 2004, at Cl.

28 Videotape: Sustained Inattentional Blindness-Selective Looking (Daniel J. Simons, 2004), available at http://viscog.beckman.uiuc.edu/djs_lab/demos.html. 
suit walking among the crowd in the video. Most did not. ${ }^{29}$ Yet when the video is repeated the presence of the gorilla is clear and striking to everyone. The point is that perceptions are a product of prior expectations, especially when one is concentrating on something else. This is related to a phenomenon psychologists call cognitive conservatism, the tendency not to perceive a change in one's surroundings or situation because expectations are built around the situation as it had been. ${ }^{30}$

At the risk of oversimplification, my sense is that many (though certainly not all) actors caught up in financial scandals failed to notice the gorilla. Take a lawyer working for Enron, working excessively long hours in structured finance to put together a series of special purpose entities. The prevailing "schema" and task definition are narrow and focused; it becomes entirely possible that disconfirming information remains outside of attention until the problem is exposed in a vivid, salient fashion. If we ask whether the actor was actually aware of the fraud, the answer will often be "no." This is so even if we shift to the recklessness component of scienter, which most all courts now define as "highly unreasonable omissions or misrepresentations that involve not merely simple or even inexcusable negligence but an extreme departure from the standards of ordinary care, [presenting] a danger of misleading buyers or sellers which is either known to the defendant or is so obvious that the defendant must have been aware of it." "This is a "subjective" standard of recklessness, essentially asking whether the defendant was aware that he or she didn't know whether what was being said was true (even though it might be). Once we start asking whether the risk was known or so obvious that the defendant must have been aware of it, we run into the same problem of biased perception.

Of course, as noted earlier, a defendant will only be found to lack awareness if the judge or jury so determines, and there are ample reasons to doubt whether they will be inclined to accept a claim of a schema-based defense. This is much the same as the hindsight bias problem: the jury will be told and shown that (metaphorically) the gorilla was in the room, and it may well then seem "so obvious that the defendant must have been aware of it."

If judges and juries make such inferences, there will be more findings of scienter than the law-strictly construed-would warrant. Whether this is good or bad as a matter of policy is open to question. One could certainly argue that, in light of the cognition literature, we ought to move away from knowledge or subjective awareness in favor of something like negligence or gross negligence if we want the law to have its desired deterrence or compensatory effect. And judges and juries may be applying the law as if that were the standard. But if

29 I certainly did not when I first viewed the video.

30 See Sara Kiesler \& Lee Sproull, Managerial Responses to Changing Environments: Perspectives on Problem Sensing from Social Cognition, 27 ADMIN. SCI. Q. 548 (1982). For an example with significant legal implications, see Dennis A. Gioia, Pinto Fires and Personal Ethics: A Script Analysis of Missed Opportunities, 11 J. Bus. ETHICs 379 (1992).

31 Broad v. Rockwell Int'l Corp., 642 F.2d 929, 961-62 (5th Cir. 1981), cert. denied, 454 U.S. 965 (1981). 
so, we ought at least appreciate the acoustic separation between the law as articulated and the law as applied. In turn, if we come to see that some lower state of mind standard is actually being applied-i.e., that many actors found to have violated Rule $10 \mathrm{~b}-5$ did not have a contemporaneous appreciation that they were complicit in a fraud-we might want to rethink how we punish them. They may still be worthy of liability simply because we want to encourage greater watchfulness or see the victims compensated, but we should not necessarily tar them with labels of corruption or venality unless we simply want to act out a morality play in more vivid shades of black and white. ${ }^{32}$

Now let us return to Martha Stewart. If we assume that there was inside information passed on by Bacanovic's assistant and no pre-existing instruction to sell, it is not easy to make a case of cognitive blindness when she said otherwise to investigators and the public. (To be clear, I think the above discussion applies more easily to financial frauds that were characterized by a high degree of informational and normative ambiguity, as I have explored elsewhere.). ${ }^{33}$ If asked to speculate, I would guess that Stewart suffered from an illusion of control typical of highly successful executives: the belief that bluffing and dissembling was something she had done well many times before and could get away with again, especially as against "mere" government functionaries and a manipulable public.

But I am not entirely sure of that. We do know from reports that she had met with Bacanovic a couple of weeks before and that selling ImClone had been discussed. (More on this meeting later). Perhaps a figure of $\$ 60$ was mentioned. Would it be possible that she was led to recall that meeting as coming to such an understanding, so that the ImClone stock was supposed to have been sold when the price dropped to that level? Cognitive research does show that motivation can bias recollections even with respect to fairly objective factual matters.

Of course, Stewart allegedly told investigators more than that-she made other misstatements about the phone call, and supposedly tried to alter documents-and these were the false statements upon which she actually was convicted. ${ }^{34}$ With respect to these, awareness would be harder to deny. At this point, the more plausible account would be that if she had convinced herself that she was in fact not guilty of insider trading, she felt justified in misrepresenting certain facts that otherwise looked bad (for example, the fact that there was a phone call from the broker followed quickly by the sale, or that there was no good documentation of the instruction to sell). That is an all-too-

32 But see infra note 53, Donald C. Langevoort, Rereading Cady, Roberts: The Ideology and Practice of Insider Trading Regulation, 99 COLUM. L. REV. 1319 (1999) [hereinafter Langevoort, Rereading Cady, Roberts].

33 See Donald C. Langevoort, Technological Evolution and the Devolution of Corporate Financial Reporting, 46 WM. \& MARY L. REV. 1 (2004).

34 The jury did not convict based on the $\$ 60$ "understanding," which was significant because of concerns that later surfaced that an expert witness for the prosecution committed perjury in his testimony. See United States v. Stewart, 323 F. Supp. $2 d 606$ (S.D.N.Y. 2004), aff'd, 433 F.3d 273 (2d Cir. 2006). 
human form of moral rationalization, ${ }^{35}$ but as we saw above, nothing that undercuts a finding of scienter. As such, I suspect that her awareness in June would satisfy even a psychologically rigorous test for scienter.

\section{MARTHA STEWART'S INSIDER TRADING}

There was no trial with respect to allegations of insider trading by Martha Stewart because the prosecution chose not to charge her with such. Many observers viewed that as awkward, predicting that the jury would not be sympathetic to a claim of lying to investigators about conduct that the prosecutors decided wasn't unlawful. In hindsight, we know that the prosecution's strategy worked anyway.

The implicit message, however, was that there were flaws in the insider trading case that made it dangerous (or at least complicating) to take to the jury. ${ }^{36}$ What were they? Much of the discussion has been with respect to the particular use of the misappropriation theory of liability that would be necessary to create liability. Though that may be partially so, I think that we also have to return to the scienter requirement.

The SEC's civil case against Stewart is fairly clear in its theory of liability. The material non-public information was the fact that the Waksals were selling, which allegedly was passed on in the telephone conversation just before Stewart unloaded her holdings of ImClone. Information that a controlling shareholder was secretly trying to sell off his own and family shares does seem to be the sort that a reasonable investor would likely consider important-the legal test for materiality.

This misappropriation theory of liability finds a violation of Rule $10 \mathrm{~b}-5$ when a person who is "entrusted" with confidential information secretly breaches his fiduciary duty by tipping or trading. ${ }^{37}$ The SEC's claim (which presumably is the same as what prosecutors would have alleged had they brought the case) was that Bacanovic was the misappropriator, under a duty to Merrill Lynch and his customer to respect the confidentiality of any one customer's trading. Merrill indeed makes its official policy to that effect clear in training and compliance manuals. When he passed the information on to Stewart, he violated that expectation. As to Stewart, the misappropriation theory makes her liable as a tippee if she knows or recklessly disregards that the information has been given to her in violation of the tipper's fiduciary duties. ${ }^{38}$ The SEC emphasized that as a former stockbroker, Stewart would

${ }^{35}$ Even more so if she thought that the investigation was unfair or politically motivated. Cf. Dale T. Miller, Psychologically Naïve Assumptions About the Perils of Conflicts of Interest, in CONFLICTS OF INTEREST: CHALlENGES AND SOlUTIONS IN BUSINESS, LAW, MEDicine AND PUBlic Policy 126, 128 (Don A. Moore et al. eds., 2005) ("Much unethical behavior is justified by the sense of fairness or entitlement").

${ }^{36}$ See Michael L. Siegel \& Christopher Slobogin, Prosecuting Martha: Federal Prosecutorial Power and the Need for a Law of Counts, 109 PENN. ST. L. REV. 1107 (2005).

37 United States v. O'Hagan, 521 U.S. 642 (1997).

38 There are interpretive questions about the precise scope of tipper-tippee liability under the misappropriation theory of liability, but they would not likely operate in Stewart's 
have been aware of the confidentiality rules.

Here we can see some legal arguments on Stewart's behalf. First, in contrast to what misappropriation is normally concerned with (fiduciary disloyalty), Bacanovic's action in taking care of a major client like Stewart was arguably in Merrill's best interest. As to Merrill, in other words, he was not "feigning loyalty" while acting disloyally-the essence of misappropriation. Moreover, it would not be surprising to learn that within the brokerage community this is an informal norm of "good for business" information sharing that departs from the formal confidentiality statement in company policy. As to duties Bacanovic owed to Waksal personally, one might wonder whether Waksal really had any expectation that his trading would be kept completely confidential and not shared with someone like Stewart, who was his close friend. After all, he was aggressively getting his father and daughter out of ImClone. None of these points is a clear winner for Stewart, but it is easy to see how the government's case becomes harder in light of them.

My sense, however, is that scienter is at least as interesting an issue, and raises another potential defense. This brings us back to. Stewart's thoughtprocess on and around December 27, and here we can draw on some background facts provided by behavioral finance scholar Meir Statman in a recent paper. ${ }^{39}$ Stewart was not a very successful investor. She had a portfolio loaded with technology stocks (ImClone, in the biotech field, was one), and was badly hurt by the technology sector sell-off that occurred in 2000 and 2001 . Her portfolio value (excluding MSLO) declined from $\$ 4,530,730$ in June 2000 to $\$ 2,510,973$ in December 2001 .

What was most notable is how reluctant she was to sell her stocks, which may connect to a tendency often noted in the behavioral finance literature. ${ }^{40}$ Stewart was regularly favored with IPO allocations, meaning that she was able to buy the stocks at a deep discount to likely near-term market values. Whether or not they "flip" immediately, many investors take their profit in the nearterm. Stewart did not, holding the shares through expectedly dramatic price increases and then, later on, through the bursting of the tech stock bubble. ${ }^{41}$ She thus managed to lose money even having started in such an extraordinarily favorable position.

Whose fault this was is not clear; Stewart apparently blamed Bacanovic and Merrill. In any event, Bacanovic met with Stewart in mid-December to urge her sell her "loss" stocks before the end of the year to offset against

favor. See United States v. Falcone, 257 F.3d 226 (2d Cir. 2001).

39 Meir Statman, Martha Stewart's Lessons in Behavioral Finance, 7 J. INV. CONSULTING 52 (2005).

40 See Hersh Shefrin \& Meir Statman, The Disposition to Sell Winners Too Early and Ride Losers Too Long: Theory and Evidence, 40 J. FIN. 777 (1985). One magazine story suggests a different explanation: that Stewart often bought stocks in companies where she knew the CEO personally, and felt that selling would be disloyal. See Toobin, supra note 9, at 70-71. Indeed, Stewart had a habit of holding onto winners and losers too long. See Statman, supra note 39, at 55.

41 For example, she bought 350 shares of Palm Inc. at $\$ 38$ and watched the price go up to $\$ 95$ on the first trading day. When she sold the shares, they were trading at $\$ 3.47$. 
taxable income. They discussed each of the holdings, including ImClone, and Stewart finally sold off all twenty-two of her loss stocks on December 21 and 24 for a combined loss of $\$ 1,037,874$. Because ImClone was one of her few profitable stocks (and by far her most profitable), she held onto it. ${ }^{42}$ Crucially, Stewart said that this selling "made her stomach turn," ${ }^{, 43}$ an interesting psychological point. In fact, the tax losses were quite valuable given Stewart's other income. However, having to finally admit defeat and take the lossesnotwithstanding such potential for gain a year or two earlier-was devastating to Stewart's ego, and generated a good deal of anger and regret. So far as her investments were concerned, Stewart was in late December in an emotionally depressed state.

Then, on December 27, just three days after the stomach-turning sales were done, she got the phone call from Bacanovic's assistant indicating that her only remaining winner, ImClone, was also about to implode. One can at least appreciate what was no doubt a very emotional response-not this one, too! If she had a chance to avoid this loss by selling before the market adjusted, such risky behavior can at least be placed in context, ${ }^{44}$ though it certainly wouldn't be a defense to insider trading.

What is legally a defense is the absence of scienter. Defining scienter with respect to insider trading has been controversial, with courts and the SEC disagreeing about whether it must be shown that the defendant "used" the inside information to profit (i.e., that he traded because of the information) or whether mere possession of the information is enough, without regard to motivation. ${ }^{45}$ In 2000 , the SEC sought to resolve the controversy via Rule $10 \mathrm{~b} 5-1$, establishing an "awareness" standard that conforms closely to the prevailing standard in non-insider trading $10 \mathrm{~b}-5$ cases, as we have seen.

This controversy largely assumed that the information was material and nonpublic, however, and focused solely on whether a causal link between that information and the trading is necessary. A more subtle scienter issue is what awareness the defendant must have as to either the materiality or the non-public nature of the information when there is some ambiguity. In particular, would a defendant lack scienter if he or she thought that the information was public, even though it wasn't? Although the case law on this is sparse, it would seem

42 She had bought ImClone at $\$ 16$, and as of mid-December had a gain of some $\$ 186,000$.

43 See Statman, supra note 39, at 55.

44 See Jessica S. Lerner \& David Keltner, Fear, Anger and Risk, 81 J. PERS. \& Soc. PSYCHOL. 146 (2001) (anger leads to riskier behavior). For a good review of the research on the role of emotions in securities trading-which generally suggests that more emotional traders perform more poorly than less emotional ones-see Andrew W. Lo et al., Fear and Greed in Financial Markets: A Clinical Study of Day-Traders (March 22, 2005) (working paper, Mass. Inst. Tech.), available at http://web.mit.edu/alo/www/Papers/lorepsteen4.pdf; see also Peter H. Huang, Regulating Irrational Exuberance and Anxiety in the Securities Markets, in THE LAW AND ECONOMICS OF IRRATIONAL BEHAVIOR 501 (Francesco Paresi \& Vernon L. Smith, eds., 2005).

45 See Donna M. Nagy, The "Possession v. Use" Debate in the Context of Securities Trading By Traditional Insiders: Why Silence Can Never be Golden, 67 U. CIN. L. REV. 1129 (1999). 
so. $^{46}$

Now consider what Stewart learned from Bacanovic's assistant. Initially, there were two bits of information in the phone message-that the Waksals were selling and that Bacanovic expected the price to decline. She called the broker's assistant and learned one more fact-that the price had already fallen a good bit. My suspicion is that (especially in an angry and emotional state) she could easily construe this to mean that adverse information had already reached the market, and the big institutions were starting to bail out. She did not want to be left behind, again.

As to the Waksals' selling, I suspect that she construed this as the Waksals and much of Wall Street. In fact, it is hard to imagine (especially to a former stockbroker) that she would assume that she was being told that the Waksals were selling illegally - which would be the case if the information had not yet made it to the market. Illegal sales by senior executives do not usually occur in an unconcealed fashion through. a reputable broker. Again, the more likely inference is that word about Erbitux had become public and that the Waksals were joining the crowd.

Whether this is a successful defense as a matter of law is a bit murky. As Rule 10b5-1 shows, the SEC prefers a simplified state of mind inquiry, and could claim that even if the foregoing were true (1) Stewart still had one piece of information that the rest of the world did not, received from a private source in arguable breach of fiduciary duty; ${ }^{47}$ (2) under these circumstances, she recklessly failed to ascertain the state of public knowledge before selling; and (3) that information does not become public until it is fully internalized by the market (i.e., trading by the smart money is not enough if the price is still adjusting). ${ }^{48}$

My point is not to argue the law on these questions, ${ }^{49}$ but rather to point out that Stewart's actions may have fallen short of at least the spirit of the scienter requirement under Rule $10 \mathrm{~b}-5$, which requires conscious awareness. And even if she did act with scienter because the law (i.e., Rule 10b5-1) is construed to make scienter easier for the SEC or prosecutors to prove in the insider trading context, we see a consequence that might be somewhat troubling: people can be guilty of insider trading even under circumstances that

46 For a discussion, see DONALD C. LANGEVOORT, InSIDER TRADING: REgulation, ENFORCEMENT AND PREVENTION $§ 5.5$ (2004 ed.); see also Alan Horwich, The Neglected Relationship Between Materiality and Recklessness Under Rule 10b-5, 55 BUs. LAW. 1023 (2000).

47 See United States v. Mylett, 97 F.3d 663 (2d Cir. 1996).

48 The SEC has fairly consistently held to the view that information is not public until it is generally available to the investing public. See LANGEVOORT, supra note 46 , at $\S 5.4$.

49 The case would have been more complicated as a criminal action because courts sometimes insist on a higher level of scienter in criminal insider trading cases as compared to civil. See, e.g., United States v. Smith, 155 F.3d 1051 (9th Cir. 1998) (use rather than possession); United States v. Cassese, 290 F. Supp. 2d 443 (S.D.N.Y. 2003) (knowledge of tender offer in case brought under 14e-3), aff'd on other grounds, 428 F.3d 92 (2d Cir. 2005). 
evidence a very low level of moral culpability. ${ }^{50}$ Perhaps that is a fair trade-off with respect to civil enforcement, ${ }^{51}$ but the threat of criminal prosecution raises the stakes considerably. My impression that Stewart may have lacked a contemporaneous appreciation that this was illegal insider trading is supported by her own lack of any effort whatsoever to conceal the trading. Like the Waksals, she left the trading wide open for Merrill's internal compliance personnel and federal investigators to see. Either she made an emotional, angry decision without regard for the legal risks to avoid a tiny loss or she believed that what she did was justifiable. Probably it was a combination of the two. ${ }^{52}$ In any event, it was very different from the kinds of behavior we generally think of as core insider trading abuses. ${ }^{53}$

\section{SELF-SERVING BIASES}

Some perceptual biases (such as the gorilla example) are purely cognitive, reflecting heuristics associated with bounded rationality. Others are motivated-reality is distorted in order to maintain a preferred impression, which may be important for the preservation of self-esteem, confidence, etc. Because motivated biases are functional, they may thrive even in competitive market situations. ${ }^{54}$

Self-serving biases are likely to be especially important with respect to scienter. A great deal of research has been done on auditor perceptions and judgments with respect to client adherence to accounting standards and fair value presentation, which are often very subjective. The standard post-Enron claim is that auditors were biased because of conflicts of interest based on the provision of non-audit services; if so, the regulatory steps to eliminate nonaudit services should be a useful intervention. But a number of researchers are doubtful: they believe that auditor bias is self-serving, a way of coming to agree with the client in order to maintain and foster the audit relationship. ${ }^{55}$ If this is right, then only a more radical intervention (e.g., making the auditor see some group other than management as its "principal") will cause the realignment. And that might simply shift the direction of the bias rather than eliminate it. In any event, absent effective intervention many forms of biased auditing will be unconscious rather than intentional, raising similar scienter issues to those

50 See Carol B. Swanson, Insider Trading Madness: Rule 10b5-1 and the Death of Scienter, 52 U. KAN. L. REV. 147 (2003).

51 The core remedy in a civil insider trading case is disgorgement; other remedies (e.g., an injunction or a civil penalty) are discretionary and vary with the perceived culpability of the conduct.

52 This issue was raised by Stewart's lawyers at her criminal trial. The prosecution responded by saying that white collar criminals often do stupid things. See Toobin, supra note 9 , at 71 .

53 To be sure, the SEC treats all insider trading enforcement actions as morality plays.

See Langevoort, Rereading Cady, Roberts, supra note 32, at 1329-30.

54 See Langevoort, Organized Illusions, supra note 7, at 158.

55 See, e.g., Max Bazerman et al., Why Good Accountants Do Bad Audits, HARV. BuS. REV., Nov. 2002, at 97. 
discussed above.

Recent research on conflicts of interest-which are of course a central concern of securities regulation ${ }^{56}$-is particularly intriguing. A series of studies demonstrates that the disclosure of conflicts of interest is not always productive, for two reasons. ${ }^{57}$ One is that the recipient of the disclosure is insufficiently self-protective. The more interesting is that the disclosure gives the person with the conflict a self-serving excuse to be opportunistic. If the discloser's perception is that the recipient has been given fair warning, it becomes easier to perceive opportunism as fair play rather than a violation of trust. As such, scienter may be diminished or lacking, because the person making the disclosure will not necessarily be aware that the opportunism is misleading.

\section{CONCLUSION}

Our clinical inquiry into the securities fraud cases against Martha Stewart that never happened considered only one dimension to an interesting event. Others have looked at the case with a view toward other dimensions: ambiguities in the law of insider trading, for example, which permit factors such as envy, gender bias, or political bias to have an undue influence on prosecutorial decisions or trial outcomes, ${ }^{58}$ or how celebrities are treated in the judicial system. I do not mean in this brief paper to have looked at the case from all angles.

Rather, my aim has been to stay close to the behavioral law and economics project. Legal standards that require some element of subjective intent, willfulness or bad faith are usually imposed to describe highly culpable forms of behavior, thereby justifying harsh liability consequences. Securities fraud is certainly such, and recently the view has grown that those who commit securities fraud are bad actors deserving punishments that substantially exceed even those attaching to most violent crimes.

My sense is that culpability with respect to securities fraud is in fact very hard to parse out, running a broad range from the truly sociopathic (scams that prey on and devastate the finances of the unsuspecting elderly) to conduct that should have been better but reflected a good bit more myopia, rationalization, and self-deception than any deliberate deceit. Used carefully, the tools of cognitive and social psychology under the rubric of behavioral law and

${ }^{56}$ See, e.g., Jill E. Fisch \& Hillary A. Sale, The Securities Analyst as Agent: Rethinking the Regulation of Analysts, 88 IOWA L. REV. 1035 (2003).

57 See Daylian M. Cain et al., The Dirt on Coming Clean: Perverse Effects of Disclosing Conflicts of Interest, 34 J. LEG. STUD. 1 (2005).

58 See Jeanne L. Schroeder, Envy and Outsider Trading: The Case of Martha Stewart, 26 CARdozo L. Rev. 2023 (2005); Daniel C. Richman \& William J. Stuntz, Al Capone's Revenge: An Essay on the Political Economy of Pretextual Prosecution, 105 Colum. L. Rev. 583 (2005); Joan MacLeod Heminway, Save Martha Stewart? Observations About Equal Justice in U.S. Insider Trading Regulation, 12 TEX. J. WOMEN \& L. 247 (2003). On the aspects of the case that emerged after the trial and conviction, see Kathleen F. Brickey, Mostly Martha, 44 WASHBURN L.J. 517 (2005). 
economics can be of substantial help in parsing out how people (including, and perhaps especially, those who thrive in corporations or financial markets) perceive information and make judgments, which in turn will get us much closer to what those suspected of fraud were thinking, how much blame and punishment is deserved, and how the law might be reframed to encourage more thoughtful assessments of culpability. 
Heinonline -- 10 Lewis \& Clark L. Rev. 182006 